\title{
Şeyyad Hamza'nın Yûsuf ve Zelîhâ mesnevisinde estetik anlatı boyutu
}

\section{Salih UÇAK ${ }^{1}$}

\begin{abstract}
APA: Uçak, S. (2019). Şeyyad Hamza'nın Yûsuf ve Zelîhâ mesnevisinde estetik anlatı boyutu. RumeliDE Dil ve Edebiyat Araşttrmaları Dergisi, (17), 154-166. DOI: 10.2900o/rumelide.656667
\end{abstract}

\section{$\ddot{O} \mathbf{z}$}

Son zamanlarda edebiyat sahasındaki kadim metinlerin farklı yaklaşım ve tekniklerle yeniden okunup değerlendirildiğini görmekteyiz. Edebiyatçılar, edebi metinlerin batı referanslı yöntemlerle günümüz algı ve yorumlamalarına açık bir formda işlenmesi gerektiğini sıklıkla dile getirmektedir. Kurguya bağlı metinlerin estetik boyutlarına dair yapılan incelemeler, yeni bir ufuk açısından kıymetlidir. Özellikle anlatı dünyasına ait gelişen yeni literatür, bu tür çalışmalara zemin hazırlamaktadır. Anlatmaya bağlı edebi metinlerden mesnevi, estetik kurallara bağlı kalınarak oluşturulduğu için günümüzde romans veya roman olarak kabul edilip bu türlere göre yeniden okunmaktadır. Anlatı düzlemleri, alt ve üst kurmaca kimliğiyle mesnevi, bu bahsettiğimiz yeni bakış açıları bakımından yorumlanabilmektedir. Mesnevi, estetik anlatı boyutu itibariyle imaj ve imge açısından zengin bir malzeme taşımaktadır. Anlatıdaki dil olgusu, olay örgüsünden çok, karakter çizimi üzerinde yoğunlaşır. Buna göre geçmişe ait bilinen metin ve olaylardan hareketle yeni bir anlat düzlemi oluşturmak, anlatıcı için daha öncelikli bir konudur. Yûsuf ve Zelîhâ mesnevisinin birbiriyle ilgili kurgusal birimleri, metin bütünlüğü içinde ana olaya bağlı tali olayların oluşturduğu bir yapıya işaret eder. Kutsal metinden hareketle oluşturulan bu anlatı kompozisyonunda sanatçının kullandığ dil ve ifade kalıpları, tam anlamıla “edebî” olmayı zorunlu kılar.Bu bağlamda çalışmamız, Şeyyad Hamza'nın Yûsuf ve Zelîhâ mesnevisinde anlatıcının estetik tavrını ortaya koymak; dil olgusu ve anlatım açısından geleneksel olanla modern olanı karşılaştırmak, mitik ve mistik yapıyı irdelemektir.

Anahtar kelimeler: Şeyyad Hamza, Yûsuf ve Zelîhâ, estetik, anlatı, mesnevi.

\section{Aesthetic narrative dimension in Şeyyad Hamza's mesnevi of Yusuf and Zeliha}

\begin{abstract}
Recently, we see that the ancient texts in the field of literature are re-read and evaluated with different approaches and techniques. Literary researchers often point out that literary texts should be explicitly processed in today's perceptions and interpretations using western-referenced methods. Investigations on the aesthetic dimensions of texts based on fiction are valuable in terms of a new horizon. Especially the new literature that develops in the narrative world prepares the ground for such studies. Since mesnevi, which is one of the literary texts connected to narration, is created by adhering to aesthetic rules, it is accepted as romans or novel and is re-read according to these genres. The narrative planes, mesnevi with their lower and upper fictional identity can be interpreted in terms of these new perspectives. Mesnevi carries a rich material in terms of image and symbol in terms of aesthetic narrative dimension. The language phenomenon in the narrative focuses on character drawing rather than plot. Accordingly, creating a new narrative plane based on the known texts and events of the past is a priority for the narrator. The interrelated fictional units of Yusuf and Zeliha mesnevi point to a structure of secondary events connected to the main event within the text
\end{abstract}


integrity. In this narrative composition based on the sacred text, the language and expression patterns used by the artist necessitate being literally "literary". In this context, our study is to reveal the narrator's aesthetic attitude in Shayyad Hamza's mesnevi in Yusuf and Zeliha; to compare the traditional with the modern in terms of language and expression, to examine the mythical and mystical structure.

Keywords: Shayyad Hamza, Yusuf and Zeliha, Aesthetics, Narrative, Mesnevi.

\section{Giriş}

Şeyyad Hamza, kuruluş dönemi klasik Türk edebiyatının öncülerinden biridir. Hakkında detaylı bilgi sahibi olamadığımız şairin XIV. yüzyılda yaşadığı bilinmektedir. Konusu kutsal kitaplarda geçen Yûsuf ve Zelîhâ hikâyesi, şairin tanınmasını sağlayan mesnevisidir. Klasik edebiyatta mesneviler, çoğunlukla ikili aşk kahramanları üzerine bina edilir. Birer romans örneği olarak kabul edilen bu mesneviler, anlatı düzlemi bakımından dikkat çekici özellikler taşımaktadır. Anlatı için estetik bir araç olarak görülen mesneviler, sanatçının dil ve düşünce dünyasını yansıtması bakımından önemlidir. Mesnevilerde asıl gaye, vaki olanı anlatma veya hikâye etme değil; biçim ve içerik estetiği açısından hüner göstermektir. Şeyyad Hamza, Yûsuf ve Zelîhâ mesnevisinde kurmaca dünyasının kendi gerçekliği içinde mitik ve mistik bir anlatının kapılarının açar. Modern romanın aksine metafizik boyutu önceleyen ve bunu anlatı boyunca güncel tutan sanatçı, geleneğin bilinen sınırları içinde farklı bir edebi duruşu resmeder. Metafizik doku, soyut ve öznel bir anlatı tercihi ile olay örgüsü içinde boğumlanarak devam eder. Manzum bir anlatı örneği olarak mesnevi, söylemde ve kurguda estetik bir tavrı zorunlu kılar. Biçim ve içerik mükemmelliği, eserin irreel yapısıyla birleşir. Birey odaklı bir anlatı olarak Yûsuf ve Zelihhâ mesnevisi, dramatik yapının sunumunda okuyucuya edebi hazzın nirengi noktalarını sunar. Mesnevi, estetik anlatı boyutu itibariyle imaj ve imge açısından zengin bir malzeme taşımaktadır. Anlatıdaki dil olgusu, olay örgüsünden çok, karakter çizimi üzerinde yoğunlaşır. Bu bağlamda geçmişe ait bilinen metin ve olaylardan hareketle yeni bir anlatı düzlemi oluşturmak, anlatıcı için daha öncelikli bir konudur. Anlatıda anlatıcının "müşahit" kimliği, kurmacanın okur merkezli bakış açısında daha mesafeli bir konumu işaret eder. Bu konum, anlatıcının tahkiye tavrında didaktik bir etki oluşturur.

Yûsuf ve Zelihhâ mesnevisinin birbiriyle ilgili kurgusal birimleri, metin bütünlüğü içinde ana olaya bağlı tali olayların oluşturduğu bir yapıya işaret eder. Olaya bağlı diğer metin türlerinde olduğu gibi bu yapı, dizgesel bir okumaya tabi tutulduğunda klasik metinlerin ana ekseninde bulunan parça güzelliği dışında anlatının tamamına sirayet eden bir yöne evrilir. Olaya odaklanan kurgusal anlatım, tali olaylar ve metafizik göndermelerle beraber okura apayrı pencereler açar. Anlatıcının anlatıya kattığı anlam daha çok burada devreye girer. Olayı estetize etmeden anlatının organik bütünlügüne hükmetmenin imkânsızlığını bilen sanatçı, imge ve sembollerle amacına ulaşmayı hedefler. Kutsal metinden hareketle oluşturulan bir anlatı kompozisyonunda sanatçının kullandığı dil ve ifade kalıpları, tam anlamıyla “edebî” olmayı zorunlu kılar. Alelade bir dil ve anlatım, böyle bir hikâye için kabul görmez. Sanatçı bunun farkındadır ve şöyle der:

Budur âhir kıssalaruy görklüsi

Kur’ân içre mushaflaruy yazusı

$(2 \mathrm{a}, 16)^{2}$

Çalışmada kullanılan beyitler, İbrahim Taş’ın hazırladığı "Şeyyad Hamza Yusuf ve Zeliha” adlı çalışmadan alınmıştır (Ankara, 2010). Yusuf u Züleyha mesnevisinin bilinen tek yazması Türk Dil Kurumu Kitaplığında A/301'de kayıtlı bulunan Kitâb-ı Güzîde'nin içinde yer almaktadır. Yazma h. 952 (m. 1545) yılının Zilhicce ayında istinsah edilmiştir. Müstensihin Hasanoğlu Kâsımoğlu 'Abdu'r-rahmân olduğu eserin sonunda belirtilmiştir. Yazma 103 sayfadan oluşmakta ve her sayfada genellikle 15 satır bulunmaktadır. 
Kurgusal yapıda "kutsal göndermeler"in eksik olmadığı bir metin olarak Yûsuf ve Zelihhâ mesnevisi, ahlaki anlatım unsurlarını, olaylarla somutlayan bir nitelik taşır. Bu yönüyle klasik edebiyattaki pek çok mesnevide bu somutlamayı görmek mümkündür. Çağrışım değeri zengin sembol ve imgelerin hâkim olduğu Divan edebiyatındaki anlatı metinleri, bu itibarla daha dikkatli bir gözle yeniden okunabilir. Dursun Ali Tökel, kurmaca bir anlatı olarak mesneviyi değerlendirirken mesnevinin kendisi kendisi için olmayan edebi bir metin (Tökel, 2011, s. 171) tanımını kullanır. Mesnevinin çoğul gösterenli bir anlatı olması bu tanımlamayı gerektirir.

Klasik anlatı metinlerinde eksik olmayan "santimantal boyut" hem tahkiye toplumunun bir gereği, hem de duygusal gerilimin vazgeçilmez sürükleyici öğesi olarak görülmelidir. Cenk-nameler dışında kalan hemen bütün klasik metinlerde "aşk" teması etrafında bu santimantal atmosferin itinayla oluşturulduğunu fark ederiz. Anlatıcının anlatı formu olarak "şiir", bu duygusal atmosferin oluşumunda doğrudan bir etkiye sahiptir. Anlatı önermeleri, manzum ve nesir araçlarındaki ifade imkânları, sanatçının kendi sanatını icra ederken seçtiği temel malzemeler olarak karşımıza çıkar.

\section{Mesnevide kurgu ve anlatı düzlemleri}

\subsection{Olay}

Mesnevide bölüm ve birimler arasındaki aksiyonu kolaylaştıran tematik yapı; aşk, sabır ve sadakat üzerine bina edilmiştir. Aşk imtihanının zorluğu, tesadüfler ve çıkış yolları, beklenmedik hamleler aksiyonun merakla devam etmesini sağlamıştır. Mesnevideki entrik unsur, öyküyü sıradanlıktan kurtarıp bir anlam oluşturma çabasıyla dramatik aksiyonu her an yeniden meydana getirir.

Estetik anlatılarda olay çoğunlukla ikinci plana atılır. Olaya bağlı bazı estetik anlatılarda neredeyse vaka zincirine rastlanmaz. Ayrıca bu tür anlatılarda olaylar tek bir düzlemde ilerlemez. Genelde üst bir anlatı ve bu üst anlatı çerçevesinde gelişen alt anlatı ya da anlatılara bağlı olarak gelişir. Sanatçının fantastik bir atmosfer oluşturduğu kurgusal yapı, her yönüyle ana çerçeveye giden bütünlüğü sağlamaya yöneliktir.

Normal şartlarda "klasik anlatılarda olay unsuru önceliklidir. Bu eserlerde başat öge, olaydır. Diğer ögeler olay unsuruna yardımcı ve araç konumundadır. Olaylar, oluş sırasına göre takdim edilir. Olayın sunuşu, ya sebeplerden sonuca, ya da sonuçlardan sebebe şeklindedir (Çetin, 2003, s. 233-234). Yûsuf ve Zelîhâ mesnevisinde ise olaydan çok kişiler ön plandadır. Dolasıyla kahramanların bir "tip" olarak öne çıkması ve onların tasvir ve tahlil edildiği bölümlerin varlığı, mesneviyi "estetik bir anlatı" boyutuna taşımada önemli bir rol oynamaktadır. Mesnevide olayların oluş sırasına göre anlatıldığını, geriye dönüş(flashback), özetleme ve diyalog gibi zamanda kırılma tekniklerine, ihtiyaç duyulduğunda başvurulduğunu söyleyebiliriz. Şeyyad Hamza olayı anlatmadan önce "kahramanı" tasvir eder:

Yûsuf adlu vardı bir oğlı anuy

İmdi ȩşit bu sözi varsa cânuy

Yẻdi yaşında idi Yûsuf nebî

Sûratı hûb yoğ-ıdı anuy gibi 
Bir gėce yatur-iken ol düş görer

Ėrte turur anı Ya'kûb'a sorar

$$
(2 \mathrm{a}, 19-21)
$$

Fantastik anlatılarda, kahramanın evini/yurdunu terk etmesine neden olan olaydaki sembollerin her biri dramatik aksiyonda yer alacak bir halkanın ilk göstergesi olarak karşımıza çıkar. Yusuf un gördügü malum rüya, onun evi terk etmesine sebep olacak "ilk gösterge"dir. Rüya ile başlayan ayrılık işareti, hikâyenin ilerleyen birimlerinde "kuyu" metaforu ile devam edecektir. Kahramanın yazgısı, aslında anlatının da yazgısıdır. Yûsufve Zelîhâ mesnevisindeki mistik ve mitik yapı tam da burada devreye girer. Mesnevideki olayın girift halkalarından biri, kahramanın kuyudan çıkarılıp bir köle olarak satılacağı "pazarlar pazarına" getirilmesidir. Getirildiği şehirde halkın çocuk Yusufla ilgili ilk tepkilerinin bir gösterge olarak somutlaşması ilginçtir. Halkı kâfir olan bu şehirdeki insanların ilk yaptığı şey, Yusufun yüzünü andıran bir "put” yapmak olacaktır. Bu bağlamda estetik anlatılarda kurgunun karakterler üzerinden yürütülmesi, olay halkalarının kuruluş ve bağlantıları bakımından dikkat çekicidir.

\author{
Aya yakın var-ıdı bir şâr dahı \\ Kavmi ol şahruy kâfir idi dahı \\ Çünki Yûsuf yüzini gördi bular \\ Yûsuf'a beyzedü bir but yondılar
}

(10a, 265-266)

Mircea Eliade, anlatılardaki kahramanlar üzerinden "her birey iyi veya kötü talihi hesaba katar" (Eliade, 1994, s. 127) tespitinde bulunarak aslında hayatın reel boyutuna atıfta bulunur. Buna göre Yûsuf ve Zelîhâ mesnevisinde "rüyalar” ın karşılıklı görüldüğünü, yazgının hiçbir zaman devreden çıkmadığını fark ederiz. Yusuf’un Kenan çölünde gördüğü rüyanın Mısır’da Zelîhâ’ya ayan olacağını bilmek gerek:

Kızı Zelihâ düşde gördi bir sûrat

Yûsuf undı düşde gördi ol sûrat

Âşık olur bir nazarda surata

‘Âşık olan nėce uyuya yata

(12a, 329-330)

İzleksel kurguda, tematik değerler belirlenirken kişiler düzleminde mutlaka karşıt değerler de belirlenir. Yusuf'un müjdelendiği "sahih rüya"nın karşısında onu "imtahan"a çağıracak bir rüyanın senkronik olarak bir başka mekanda aynı bağlamda görülmüş olması okuyucu için bir "tesadüf” olsa da kurgu ve yazgı için asla bir tesadüf değildir:
Sûrat eydür ol benem Mısr 'Azîzi
İster-isey Mısr’a gel görgil bizi
Oyanu gelür Zelîhâ uyhudan
Beyzi güler olur emîn kayğudan 
Atasına eyidür baba düşüm

Gèrü gördüm bu gèce keydür işüm

$(12 b, 342-344)$

Yusuf suretinde put yapmayı düşünen şehrin ötesinde O'nu sadece rüyasında gören Zelîhâ’nın bütün işi gücü bırakıp Yusuf'u her yerde, her şeyde görme arzusu olaya dramatik boyutlar katar:
Kamu nesnesin Zelîhâ unudur
Ne ki görse eydür uş Yûsuf budur
Tursa otursa Yûsuf'ı söylenür
Kanda kim varsa anı zikr eylenür

$$
\text { (15b, 427-428) }
$$

Her edebi metni kendi devrine göre okuyup yorumlamak, dönemin şartlarını ve zihni yapısını göz önüne almak araştırmacı için zorunlu bir kıstastır. Başa gelen çekilir misali Yusuf un eylemsizliğiyle Yakub’un belli bir noktadan sonraki teslimiyetini buna yormak gerekir. Kaderci, ya da "kadere iman" $n$ bir sonucu olarak mutlak bir tevekkülle karşılaşırız. Kahramanın bir özne olarak iradi bir eylemsizlik içine girmesi bu yönüyle anlaşlabilir bir durumu ortaya koymaktadır. Yavuz Bayram, bunu "rıza ve teslimiyet" olarak değerlendirir. Ona göre kahramanın olgunlaşma sürecine kader ve olaydaki diğer kişiler etki eder. Kahramanın manevi yeteneklerinin gelişmesi buna bağlıdır (Bayram, 2017, s. 21-22)

Yûsuf ve Zelîhâ mesnevisinde asıl odak, Zelîhâ'nın Yusuf'u arzuladığı ve gömleğin arkadan yırtıldığı an'da saklıdır. Hikâyedeki kırılma noktasını bu birim oluşturur. Yusufun gördüğü rüya ile Zelîhâ'ya ayan olan "suret"in buluşma ve ayrılma sahnesi, anlatının bu halkasına eklenmiştir. Yusufun imtihandan "ismet”le çıkması, Zelîhâ'nın dayanılmaz mağlubiyetini Kernberg'e göre okursak "öznel bir anlamsızlık ve derin bir boşluk”la açıklamamız gerekir (Kernberg, 1999, s. 195).

Çalab 'ismet kapusın aya açar

Fâhiş işden yı̆̆lınur Yûsuf kaçar

Zelhâ komaz Yûsf’ı kapuya degi

Yètti tutdı yırtılur ard etegi

(19b, 546-547)

Anlatılarda kahramanın "benlikten arınması" için sınanması gerektiğini (Joseph, 2010, s. 113) biliyoruz. Bildungsromanlarda manevi biçimlenme ve kültürel değerlerin ön planda olduğunu düşündüğümüzde, kahramanın oluşum süreci yönüyle mihnet ve sıkıntılar çekmesi büyük bir lütuf olarak görülmelidir (Tökel, 2009, s. 187). Değerlerin toplumun kutsallarılya kültürel yaşantısı bağlamında çok derin anlamlar ifade ettiğini düşündüğümüzde “imtihan” kazanan Yusuf un zindanla ödüllendirilmesi(!) kabul edilebilir bir durum değildir. Burada statünün kutsal kanunla çatıştığını söylemek mümkünse de hiyerarşik duruma muhalif böyle bir eylemin "yoz"luğuyla da yüz yüze geldiğimizi görmemiz gerekir. Seçkin sınıfa ait algının tahakkümü ile yaşanan kaotik hakikatin insanlar nezdindeki ifadesi şöyle tezahür edecektir: 
Eytdiler Zelîhâ'ya gelmiş belâ

'Âşı olmış ol bir 'İmrânî kula(20b, 570)

Dertlü derdin her biri söyleşür

Zindân içre kayğuru ağlaşur

Hon-salâr u sâkî yatur bir gèce

Düş görürler her biri èşit nece

Bir 'aceb düş görür ol sâkî è yâr

Üç ulu salkum üzüm alur sıkar

$(22 \mathrm{a}, 624-626)$

İnsan ve hayat izleğine bağlı anlatılarda temel unsur “çatışma"dır. ̇yi - kötü, doğa - kişi, kişi - toplum veya kişiler arasındaki mücadeleler üzerine bina edilen çatışma, dramatik yapıyı merak unsuruyla buluşturur. Yûsuf ve Zelîhâ mesnevisinde Yusuf un zindan günleri, rüya yorumlayıp saraya dönüşü ile kardeşlerine kavuşması hep bu çatışmanın birer halkası olarak anlatı boyunca devam edecektir. Her şeyin aşkla anlatıldığı ve anlamın anlatının güzelliğiyle bütünleştiği olay, bizi “leyte şi’ri”ye3 götürecektir. Yûsuf ve Zelîhâ mesnevisinde duygusal ritüele inanan bir toplumun beklentisini görürüz. Bu duygusal ritüelin anlatının ruhuna uygun bir biçimde kurgudaki olaya sindiğini görmek de diğer bir boyutu oluşturmaktadır.

\subsection{Poetik mekân}

Mekân, anlatılarda olay ve olguların yaşandığı sahnedir. Mekâna yüklenen anlam aynı zamanda onun işlevselliğini de göstermektedir. Mekânı, anlatının estetik bir unsuru olarak kabul eden anlatıcı, ona apayrı bir kıymet verir. Tahkiyedeki anlatıcı kimlikler mekânı, salt bir tasvir ve tanıtım aracı olarak değil; poetik kaygıları da önceleyen bir unsur olarak ele alırlar. Tahkiyedeki entrik unsurla mekân arasındaki katışıksız uyum, sanatını icra eden kimliğin estetik başarısını doğrudan etkiler. Karakterlerin psikolojik durumları, duygu geçişleri ve dramatik sahneye yansıyan yaşantıları çoğunlukla mekân paralelinde gösterilmeye çalışılır. Zira mekân, duygu ve düşüncenin somutlaşmasını sağlayan ve bu yönüyle anlatıcıуı gösterme tekniğini kullanmaya zorlayan bir öge olarak görülür.

Anlatılarda mekânlar, olaydan ve olay kişilerinden bağımsız düşünülemez. Anlatının gerçeklik kazanması için gerekli olan unsurlardan biri de olgusal mekânlardır. Karakterin kimlik ve kişilik kazandığı serüvenin görünen yüzü bu mekânlar aracılığıla sağlanmaktadır.

Mekân, eserin kurmaca dünyasında yaşanan olayların geçtiği itibarî âlem olarak kabul edilir. Estetik anlatılarda mekân işlevsel bir yapıya sahiptir ve mekân uzun uzadıya tasvir edilmez. Mekândaki işlevsel ayrıntıların tasviri daha önemlidir. Üst kurmacanın hâkim olduğu anlatılarda mekân, karakterleri doğrudan etkileyen bir unsur olarak karşımıza çıkar. "Estetik anlatılarda mekân daha çok karakteri etkileyen taraflarıyla yer almaktadır” (Sağlık, 2010, s. 266). Yûsuf ve Zelîhâ mesnevisindeki mekânların hemen hepsi bu detaylara uygun olarak verilmiştir: 
Var-ıdı Ken'ân'da bir server kişi

Adı Ya'kûb kendü peyğâmber kişi

$(2 \mathrm{a}, 18)$

Saldılar Yûsufı tėz bir kuyuya

İmdi èsit n'ètdiler ana uya

Yûsuf ve Zelîhâ mesnevisinde değişimin kodlarını taşıyan mekânlar "kuyu, zindan ve saray" olarak karşımıza çıkar. Kahramanın arınma yolculuğunda mekânların olgusal nitelikleri önemlidir. Mehmet Narlı, "mekânı, tematik yapının algılanıp işlenmesini etkileyen bir kaynak" (Narlı, 2007, s. 457) olarak ele alır. Anlatılardaki mekânın şahıs kadrosunu doğrudan etkileyen ve şekillendiren bir unsur olduğunu vurgulayarak aşağıdaki beyitlere yeniden bakalım:

Hûd oturdı bị iki yüz yıl tamâm

Geldi aya Yûsuf ‘aleyhi ’s-selâm

Allâh'umdan diledüm seni görem

Bị iki yüz yll [ğam u] ğussay yèrem

Çünki gördi Hûd anı turdı örü

Eytdi yâ Yûsuf kayurma gel bėrü

(7a, 165-168)

Çocuk Yusuf un kuyudaki psikolojisi dikkate alındığında içine düştüğü çaresizlik ve yalnızlık duygusunu bertaraf etmek, ancak iki bin yl öncesinden gelecek olan kutsal bir kimlikle -Hud- mümkün olur. Bu duruma eşlik eden masalsı gerçekle mekân arasındaki illiyet bağı fantastik kurgu açısından önemlidir. Anlatıcı, mekân betimlemesiyle kahramanın bakış açısı arasında bağ kurar.

Mekân tercihi, anlatı kişilerinin ruhsal durumları ve mizaçlarıyla doğrudan bağlantılı olduğu gerçeği unutulmamalıdır (Çetin, 2003, s. 166-167). Kahramanların duygu geçişlerinde mekândan kaçmak veya mekânı yaşanır kılmak, anlatıcının anlatı düzlemine katkısı bakımından dikkatle değerlendirilmektedir. Aşă̆ıya aldığımız bölümlerde kahramanların yaşadıkları mekânlar ile ruhsal durumlarına eşlik eden duygunun paradoksal yansıması vardır:

Kılalar yeşil zeberced yaprağın

Müşk ü ‘anberden èdeler toprağın

Ol direklerün biri ola zicâc

Birni dahı kılalar pîrûze 'âc

Birini ‘akîk kılalar key kızıl

Biri zebercedin ola levni yeşil 
Degme direk arası altun tegek

Salkumını incüden kılmak gerek

$(465-468)$

Zelîhâ'nın yaşadığı sarayın tasvir edildiği bu birimlere bakıldığında beklenti itibariyle istediği her şeye sahip olan kahramanın mutlu olduğu düşüncesidir. Hâlbuki arzusuna kavuşamayan Zelîhâ için sahip olunan "altının, zümrüdün ve zebercedin" hiçbir kıymet-i harbiyesi yoktur. O, zindana mahkûm olan Yusuf'a yenilmiş bir bedbahttır. Mutsuzluğunu hatta umutsuzluğunu anlatamayan Zelîhâ’nın saraya davet ettiği kadınlara bunu gösterme yöntemi, bu klasik anlatının herkesçe bilinen en can alıcı noktasını oluşturur:
Her biri aldı bıçağı eline
Ellerin toğradı turunc yerine
Ellerin toğraduğın bilmediler
Ne hod kesilen acısın tuymadılar
Eytdiler ol kamu mâ hâzâ 'l-başar
Dèdiler feriştedür uşbu meğer

$$
\text { (590-592) }
$$

Yusuf'u gören kadınların parmaklarını doğradıkları sahne, anlatılarda zor olan gösterme tekniğinin uygulandığı başarılı bir örnek olarak görülebilir. Şeyyad Hamza'nın estetik ifade yönüyle kelimelerle betimlediği tablo, mekân-insan ilişkisi bağlamında dikkate değerdir.

Mekân algısı, kahramanın duruşu, bakışı ve hayat felsefesiyle yakından ilgilidir. "Zindan” ön kabullere göre "cezalandırılmış, mahkûm edilmiş, ötekinin barındığı yer" olarak algılansa da Yusuf için "güvenli liman” geleceğini ihya edecek bir mekândır. Mekânla ilgili tutum, olay ve kahraman odaklı bakışla yorumlandığında "anlatıcının algı mesafesi" ortaya çıkmış olur:
Zindân ehlin kamusın âzâd kılur
Korlar anda Yûsuf'ı yalyuz kalur
Cebre'îl şol-dem ėner gökden yère
Kıldı selâm ol Yûsuf peyğâmbere
Sabr èdüp katlanğıl uş sen bu işe
Sabr-ıla her iş çıkar bir gün başa

$(21 \mathrm{~b}, 611-613)$

Klasik mesnevilerde geçen mekân, her ne kadar şiirsel ve irreel de olsa olay halkalarının yerli yerine oturması, kahramanların çevresi ile tanıtılması bağlamında başarılı bir kurgu ile verildiğini görmekteyiz. Anlatıcı, kahramanın ruhsal olgunluğu ile mekân arasında daima bir bağ kurma gereğini hisseder. Başarılı mekân tasvirleri, hem dönem anlayışının hem de poetik kaygının bir tezahürüdür (Uçak, 2015, s. 102). Yûsuf ve Zelîhâ anlatısında dekoratif bir betimleme olarak çevresel mekânlar dışında olayın 
derinlik kazanması için bilinçli olarak kullanılan olgusal mekânlar ciddi yer tutmaktadır. Mekân, anlatının vücut bulması ve kendi gerçekliğini oluşturması bağlamında önemlidir. Olaydaki yaşama sinen ve bir yönüyle hayatı farklılaştıran unsur, bu olgusal mekânlardır.

\subsection{Zaman}

Estetik anlatılarda zaman; olay, anlatıcı, anlatı ve okuyucu endekslidir. Anlatıcının kurguladı̆̆ı vaka, yer ve kişi öğeleriyle tasarlanarak belli bir zaman diliminde aktarılır. Olay zamanı ile anlatı zamanı farklı olsa da anlatıcı, kurgusal anlamda olay zamanına uygun hareket eder.

Estetik anlatı zamanı, "ebediyete kavuşmak isteyen ve cidden biraz karışan zamandır" (Sağlık, 2010, s. 263). Estetik anlatılarda anlatının geçtiği süre genellikle kısa tutulmaktadır. Bazen bir günde tüm olaylar yaşanırken, bazen de sadece bir an anlatılabilir. Estetik anlatılarda olay zamanı da oldukça kısa tutulur. Zaman açısından anlatıdaki kurgu, temelde belirleyici olan unsurdur. Yûsufve Zelîhâ anlatısında zaman konusu klasik anlatılarda olduğu gibi bazen orantısız bir flashback'e tekabül eder. Yusuf'un kuyuya atıldığı sırada yardımına iki bin yll önce yaşayan Hud peygamberin gelmesi buna örnek olarak gösterilebilir:

Hûd oturdı bin iki yüz yıl tamâm

Geldi ảa Yûsuf 'aleyhi 's-selâm

Çünki gördi Hûd anı turdı örü

Eytdi yâ Yûsuf kayurma gel bẻrü

oAllâh'umdan diledüm seni görem

Bin iki yüz yll [ğam u] ğussan yèrem

(5a, 17-119)

Nurullah Çetin göre "anlatı, bir zaman sanatıdır." Geniş bir zamana yayllan olay, durum, olgu, yaşantı, duygu, hayal ve düşünce unsurlarının sergilendiği bir varlık olarak anlatı kendisinden daha fazla bir şeyi ifade eder. Geleneksel anlatılarda zaman, daha çok soyut ve genel; yuvarlak ve belirsizdir (Çetin, 2003, s. 157). Yûsufve Zelîhâ'da zamana ait belli nicel ifadeler kullanılsa da bunlar irreel ifadelerdir:

Göricek üçünci yll sordum seni

Mısr'a gel [dèdün] bulasın sen beni

Bị katır yüki haz[î]ne bağladum

Altı ay yol yörüdüm çok ağladum

(18a, 498-499)

"Zaman, hayatın doluluğu ve tamlığıdır; epiğin taşıyıcısı, organik olanın var olana direncidir" diyen Lukacs, anlatılardaki temel unsur olarak zamana vurgu yapar (Lukacs, 2007, s. 126). Mesnevi gibi olaya bağlı diğer metinlerde zaman, olay akışının belli bir düzen içinde olmasını sağlar. Paul Ricouer da zamanı anlatı ile birlikte ele alır: "zaman, bir anlatıya eklemlendiği ölçüde insana özgü bir zamana dönüşür" (Ricouer, 2007, s. 108). Yûsuf ve Zelihhâ mesnevisindeki zamanda meydana gelen kronik kırılmalar, anlatı estetiği bakımından farklı boyutların oluşmasını sağlar. Yusuf un düş ve hayallerle geri 
dönüşler veya ileri dönük öngörülerde bulunması, tahkiye zamanı bakımından dramatik kurguya yön vermiş olur. Anlatıların yaşanabilir ve daha insani bir karakter kazanması için cari bir zamana ihtiyaç vardır. Bu bağlamda Yûsuf ve Zelîhâ anlatısındaki zaman, insana özgü bir dönemi vurgulamaya yöneliktir.

\subsection{Anlatıcı ve bakış açısı}

Bakış açısı ve anlatıcı meselesi; anlatıyı anlam, duygu ve düşünce dünyası bakımından görüp değerlendirmeyi ifade eder. Bakış açısı, anlatma esasına bağlı metinlerde vak'a zincirlerinin ve bu zincirin meydana gelmesinde kullanılan mekân, zaman ve şahıs kadrosu gibi unsurların kim tarafından görüldüğü, idrak edildiği ve kim tarafindan, kime nakledildiği meselesidir (Aktaş, 1991, s. 95) Anlatıcı ise, "anlatıda bulunan her şeyi okuyucuya aktaran, sunan kişidir”(Çetin, 2004). Bir anlatıda aktarılan her şey, anlatıcının bakış açısıyla okura sunulur. Modern anlatılar bir kenara bırakılırsa klasik anlatılarda iki tür anlatıcı vardır: birinci şahıs(ben) ve üçüncü şahıs(o) anlatıcı. Estetik anlatı metinlerinde iki anlatıcı türüne de rastlanır, fakat genelde birinci şahıs ön plandadır. "Estetik anlatılardaki anlatıcıların bir özelliği de, sayılarının birden fazla olabilmesidir" (Sağlık, 2010, s. 260) Bireyi konu edinen estetik metnin bireyin yaşadığı sıkıntıları daha gerçekçi sunması açısından birinci şahıs anlatıcıyı tercih etmesi karaktere canlılık ve gerçeklik kazandırması açısından önemlidir. Yûsuf ve Zelîhâ anlatısında hâkim bakış açısıyla ben anlatıcı vardır:

İmdi diplen sözüme tutuy kulak

Bir söz eydem kim şekkerden tatlurak

$$
(2 \mathrm{a}, 17)
$$

Hâkim bakış açısında anlatıcı, olay ve şahıs kadrosuyla ilgili bütün detaylara hâkimdir. Entrik kurguyu anlatırken başvurduğu diyalog ve konuşmalar, metne hareketlilik kazandırmak için gerekli bir müdahale olarak görülür:

$$
\begin{aligned}
& \text { Eydür ey baba yatardum bu gėce } \\
& \text { Bir 'aceb düş görürem ėşit nece } \\
& \text { Eydivèr ta'bîrini anuy baya } \\
& \text { Eydeyüm ol gördügüm düşi sana }
\end{aligned}
$$

(2a, 22-23)

Yukarıdaki birimlerde anlatıcı, sesini geçici olarak kahraman/lar/a teslim eder. Vaka zincirinde anlatıcının sesini teslim ettiği kahramanlar, sahip oldukları özelliklere göre konuşturulur. Çocuk Yusuf un sesinin duyulduğu bu birimler, aynı oranda "çocukça"dır. Yusuf un rüyasından haberdar olan kardeşlerin iç konuşmaları ve dertleşmeleri çoğulcu bakış açısına yaklaşan bir düzlemi hatırlatır:

$$
\begin{aligned}
& \text { Çün ėşitdiler bular uşbu düşi } \\
& \text { Tanlaşur 'acebleşürler bu işi } \\
& \text { Eytdiler sultân olursa ol bize } \\
& \text { Buyruğ ediser dur[ur] kamumuza }
\end{aligned}
$$

$(2 \mathrm{~b}, 32-33)$ 
Üçüncü şahıs anlatıcı kimliğinin öne çıktığı birimlerde daha çok genel geçer ifade, durum ve tasvirlerin yer aldığını görmekteyiz. Anlatıcının sesini teslim ettiği bölümler hariç anlatının tamamına üçüncü şahıs anlatıcının hâkim olduğunu söyleyebiliriz:

$$
\begin{aligned}
& \breve{G} \text { ıybet ètmekden dilünüz saklayuz } \\
& \text { Yohsa müzdün yazuğa döner aplayuz }
\end{aligned}
$$

$$
\text { (20b, 577) }
$$

Mesnevilerde yazarla anlatıcı kimliği sık sık birbirine karışır. Yûsuf ve Zelîhâ anlatısında anlatıcı konumlanırken her şeye hâkim, her şeyi bilen bir konum atfedilmiştir. Anlatıcı, yaşanan bütün olayları görebilen, olup bitenin neden ve sonuçlarını değerlendirebilen bir mesafededir. İlahi bakış açısıyla olay kişilerinin bütün hayat maceralarına hükmeden bir üçüncü şahısın varlığı bütün mesnevi boyunca görülür. Ancak zaman zaman konum değiştiren anlatıcının, kahramanların gözünden daha cüzi bir halkayı anlattığına da şahit oluruz.

\subsection{Dil ve üslup}

Olaya bağlı edebi bir metinle düşünce metnini birbirinden ayıran en önemli unsur dildir. Bir göstergeler sistemi olarak dil, edebî eserin varolması ve yeni boyutlar kazanması için aslolan en temel araçtır.

Edebî dil; metafor, imge ve motif gibi estetik ifadelerin yoğun olarak kullanıldığı dildir. Bu yönüyle günlük konuşma dilinden farklıdır. Doğrudan anlatma yerine dolaylı anlatıma yer verir. Müphemliklerle doludur ve edebî zevke uygun olarak pek çok keyfi kullanıma kapı aralar.

Edebî dil, çağrışım değerleriyle üst bir dil olduğunu her haliyle belli eder. Yazarın kendi kendine yeten dili şahsi bir dildir. Yazı, kolektif karakterlidir ve sanatçının içinde yaşadığı kültürden beslenir (Aktaş, 1991, s. 11) Mesnevi, tür itibariyle olaya bağlı da olsa, ifade gücünü şiirin estetik yapısından alır. Fesahat ve belagata uyma kuralı gereğince Şeyyad Hamza’nın da edebi bir dil tercih ettiğini görürüz:

Mâmîl eydür yâ Beşîr hâzâ ğulâm

Bir oğlandur kim yüzi bedr-i tamâm

Dėdiler kullar bunı bir birine

Hocamuzuy düşi geldi yerine

$$
\text { (8a, 199-200) }
$$

Dönem itibariyle Arapça ve Farsça terkip, klişe ve kalıp ifadelerin sıkça kullanıldığı bir metin söz konusudur. Sanat yapmak gayesiyle çıkılan yolda başvurulan dil oyunları, anlatı ve anlatıcının niteliği açısından belirleyicidir. Aşağıya alınan bölümde dil imkânlarıyla Yusuf için kurulan pazar anı anlatılmaktadir:

Kotîfar söyler bezergân hocaya

Kes bahâsın kuluyı eyt nėçeye

Döndi eydür tartalum terezüden

Ağırınca kıymetî her nesneden

$(14 \mathrm{a}, 380-381)$ 


\author{
Koydı ne nakşıı anuy ne nakkâşın \\ Şöyle öger Yûsuf'un gözin kaşın \\ Ėşidür Yûsuf utanur bu sözi \\ Ol Zelîhâ hèç utanmaz kend’ özi
}

(492-493)

"Estetik bakımından sanatın en soyut şubesi olan edebiyat" (Sağlık, 2010, s. 204) dille icra edilir. Metni üreten bu estetik aracın etki alanı sonsuzdur. Okur donanımıla paralel olarak sonsuz anlam üretmenin mümkün olduğu söylenebilir.

\section{Sonuç}

Yûsuf ve Zelîhâ anlatısı, dramatik yapısıyla değerlendirildiğinde dil, anlam ve kurgu itibariyle yazıldığı döneme göre oldukça başarılı bir metin olarak kabul edilebilir. Anlatıcının anlatıya kattığı değer, onu yeniden var etme esasına dayanır. Kutsala dayanan ve hemen herkesçe bilinen bir vakayı yeniden yorumlamak ciddi riskler barındırır. Zira aynı metnin hem birçok sanatçı tarafından işlenmesi, hem de hakikate muhalif olmadan edebi bir kurgu oluşturmak kolay değildir. Klasik edebiyatın kendini bulmaya başladığı bir yüzyılda Şeyyad Hamza’nın eseri önemli bir boşluğu doldurmuştur.

Türk, İran ve Arap edebiyatında çok sıkça işlenen hikâye, anlatıcının dil, üslup ve anlatım teknikleriyle farklı bakış açıları kazanır. İçerik yönüyle ahlaki ve kutsal "ismet”"in temsilcisi olarak tasvir ve tarif edilen Yusuf, anlatıda "âşıkların önderi bir proto-tip" olarak sunulur. O, aynı zamanda günaha meylin ters yüz edilmiş ifadesi olarak karşımıza çıkar. Sembol ve imgeler üzerinden olayları yorumlama olarak okuyacağımız bu anlatı, bütün unsurlarıyla estetik bir bütünlüktür.

Tematik değerleriyle değerlendirildiğinde olay, şahıs, mekân, zaman ve üslup özellikleriyle Yûsuf ve Zelîhâ anlatısı klasik bir mesnevi, fantastik yapısıyla mistik ve mitik bir romans örneğidir.

\section{Kaynakça}

Aktaş, Ş. (1991). Roman Sanatı ve Roman İncelmesine Giriş. Ankara: Akçağ.

Bayram, Y. (2017). Bildungsroman Örneği Olarak Hüsn ü Aşk. İlmi Araştırmalar(23), 7-28.

Campbell, J. (2000). Kahramanın Sonsuz Yolculuğu . (S. Gürses, Çev.) İstanbul: Kabalcı.

Çetin, N. (2003). Roman Çözümleme Yöntemi. Anara: Öncü Basımevi.

Eliade, M. (1994). Ebedi Dönüş Mitosu. (Ü. Altuğ, Çev.). (Ü. Altuğ, Çev.) Ankara: İmge Kitabevi.

Joseph, C. (2010). Kahramanın Sonsuz Yolculuğu. (S. Gürses, Çev.) İstanbul: Kabalcı.

Kernberg, O. (1999). Sinır Durumlar ve Patolojik Narsisizm. (M. Atakay, Çev.) İstanbul: Metis .

Lukacs, G. (2007). Roman Sanatı. (C. Soydemir, Çev.) İstanbul: Metis.

Narlı, M. (2007). Şiir ve Mekân. Ankara: Hece.

Ricouer, P. (2007). Zaman ve Anlatı: Bir. (M. Rifat, \& S. Rıfat, Çev.) İstanbul: YKY.

Sağlık, Ş. (2010). Popüler Roman Estetik Roman, Akçağ Yay., Ankara. Ankara: Akçă̆.

Taş, İ. (2010). Şeyyad Hamza Yusufve Zeliha. Ankara: ekitap.kulturturizm.gov.tr.

Tökel, D. A. (2009). Bir Bildungsroman Olarak Leyla vü Mecnun Mesnevisi. İstanbul: Kesit. 
166 / RumeliDE Journal of Language and Literature Studies 2019.17 (December)

Aesthetic narrative dimension in Şeyyad Hamza's mesnevi of Yusuf and Zeliha / S. Uçak (pp. 154-166)

Tökel, D. A. (2011). Kurmacadan Anlatıya: Kendisi Kendisi İçin Olmayan Metin Olarak Mesnevi. H. Aynur içinde, Eski Türk Edebiyatı Çalışmaları VI, Mesnevi: Şïrin Hikayesi (s. 171). İstanbul: Turkuaz.

Uçak, S. (2015). Hâşimî’nin Mihr ü Vefâ Mesnevisinin Tenkitli Metni ve İncelemesi. Yayımlanmamış Doktora Tezi. Elazığ: Frrat Ünv. Sosyal Bilimler Enstitüsü. 